Available online at www.jmle.org

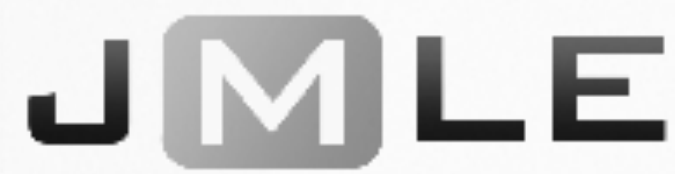

The National Association for Media Literacy Education's

Journal of Media Literacy Education 9 (1), 99 - 115

\title{
Measuring Media Literacy for Media Education: Development of a Questionnaire for Teachers' Competencies
}

\author{
Mathea Simons, Will Meeus and Jan T'Sas \\ University of Antwerp, Belgium
}

\begin{abstract}
Effective media education requires that teachers have sufficient media literacy competencies as well as the competencies to promote media literacy in students. This article describes the development of a questionnaire to measure these competencies individually or as a team. The questionnaire was developed in five stages. A systematic and critical listing of existing inventories resulted in a preliminary questionnaire. In the final stage, the questionnaire was submitted to a representative sample of 454 teachers and 219 student teachers, and an exploratory factor analysis was conducted. The results show that the questionnaire is sufficiently valid and reliable.
\end{abstract}

KEYWORDS: media literacy, media education, teachers, questionnaire

Within the media landscape, technological innovations are introduced at an accelerated pace, and the supply of digital applications and sources increases exponentially (Segers and Bauwens 2010). New media offer a range of opportunities and benefits. They allow us to easily look up information, to maintain social contacts and to create and share information. We exploit these possibilities but, at the same time, we need to assess them continually, select in the offer and choose how to deal with them, because, apart from opportunities and benefits, new media also present challenges and possible dangers. The quality of media content is an important issue, as well as the commercial influence and the potential social risks (Meeus et al. 2014a).

In order to integrate a proper use of media in our daily lives, a certain degree of media literacy is necessary. Within the literature several definitions of 
media literacy are used. Existing definitions differ in regard to the content level (knowledge, insights, skills, attitudes), the context (e.g. social, educational, commercial) and the actor involved (e.g. scientist, policy maker, developer). In this article, media refers to classic and new media, analog and digital media, personal as well as mass and social media. It includes media devices and media content, aspects of technology as well as media industry. Literacy is a contextual and dynamic concept. New technologies and new media applications induce new types of linguistic activities and therefore new forms of literacy. In this article, media literacy is broader in scope than the mere use of applications. It also includes a critical understanding of media (Cortoni et al. 2015), an enjoyable media experience (Fry 2015) and an active participation in society and citizenship (NAMLE; Baran 2009; Potter 2013; Silverblatt et al. 2014).

\section{Media Literacy in Education}

Media literacy empowers people to actively participate in society. Although family obviously plays an important role in this matter, media are not confined within the walls of the parental home. Educational institutions therefore bear a major responsibility to prepare learners (pupils and students) to use media appropriately. The pervasiveness of media is making it necessary to regulate the presence and use of media in the school context (e.g., the use of mobile phones by students or their internet behavior within the school walls). To some extent, such regulation implies restricting media use, but more importantly, education can help students become media literate by teaching them how to cope with the opportunities and risks associated with media. Promoting the media literacy of students is part of the pedagogical mission of education, similar to traffic initiation, sustainable education, social training, and other aspects of global life. Explicit media education is vital to stimulate students' media literacy. Education should pay attention to an active and creative use of media as a learning tool, within and outside the school walls, as well as to a critical reflection on the impact of media in society. Furthermore, education should promote reading and increase literacy and knowledge of current affairs in students.

Media literacy can be integrated in education in several ways (Friesem 2013; Friesem et al. 2014; Neag 2015). First, teachers can foster media literacy using the content of specific subjects: media literacy plays an important part in arts and music courses (visual and audio literacy); language courses, especially within mother tongue education, with a focus on the communicative function of media (reading and understanding several text types); and in courses such as history, geography and the sciences, which offer possibilities to promote media literacy by making learners search, analyze, and present information. In addition, however, it is necessary to address media literacy explicitly in the curriculum by discussing media topics and issues. Schools may implement media literacy in a specific subject called "Media." Finally, schools can also adopt an interdisciplinary design to foster media literacy in students by implementing projects focusing on media literacy throughout several subjects.

In more than 50 countries, stakeholders organize initiatives to promote the use of media in education (Claes and Quintelier 2009). Several studies have been 
carried out in order to grasp the outcomes of such initiatives (frequency of use, attitude towards media, etc.) (Raeymaeckers 2004; Vandenbrande 2005; Raeymaeckers et al. 2008; Segers and Resmann 2010; Simons et al. 2015). The success rate of such initiatives particularly depends on the role and on the actions of the teachers. The compatibility between the initiatives to promote media literacy in education, the teachers' competencies in the field, and the teachers' beliefs on the importance of the topic determine whether these initiatives are accepted and successful. As is the case with other educational innovations or initiatives, preexisting beliefs function as a filter through which teachers evaluate them (Pajares 1992).

\section{Measurement of Media Literacy}

As early as 1998, Singer and Singer emphasized the need of empirical research in the field of media literacy. Other colleagues agreed and added the challenge of measuring media literacy (e.g. Bergsma and Carney 2008; Hobbs and Frost 2003; Primack et al. 2006; Tulodziecki 2012). Ever since, several instruments and scales have been developed to study media literacy, often from different perspectives.

Some scales focus on specific topics or contexts. "The few measures uncovered in the existing literature were developed to take measurements surrounding a particular media education curriculum or a particular niche within media literacy" (Arke and Primack 2009, 54). As far as the latter is concerned, we mention the example of Hargittai $(2005,2009)$ who developed, validated and updated an instrument to measure people's digital, and more specifically their web-oriented digital literacy. Other examples include Primack et al. (2006), who created a scale measuring adolescents' media literacy with regard to pro-smoking media messages, and Wade et al. (2002), who evaluated the link between media literacy and eating disorder risk factors.

Other researchers stressed the need for empirical research and measurement of media literacy in education. Arke and Primack (2009) state: "in order to show the value of the subject matter, media literacy advocates must develop and possess tools to accurately measure and report results that show the desired skill development and improvements." (55). Most of these instruments focus on media literacy in students. Hobbs and Frost (2003), for example, adapting a procedure created by Quin and McMahon (1995), developed and analyzed a set of open-ended and checklist questions about messages to measure students' skills of message analysis. Arke and Primack (2009) developed a measure of media literacy for college students, focusing on radio, television and print, including also a measurement of critical thinking. Pinto (2010) developed the IL-HUMASS survey on information literacy. This survey includes items on information search, assessment, processing and communication/dissemination. It is aimed to be applied by students, academics and librarians i.e. within the context of higher education. Chang, Liu, Lee and Chan (2011) developed a media literacy self-evaluation scale for elementary school students (MLSS). The two-factor scale measures learning with media and media communication and ethics. 
In her plan of action, Hobbs (2010) encourages the research community to "develop meaningful tests for new teachers to measure their ability to implement digital and media literacy instructional practices into the curriculum" (43). In doing so she stresses the importance of instruments in measuring teacher competencies in media literacy.

In an article on trends in approaches to learning with media and media literacy education, Tulodziecki and Grafe (2012) state that the term media competency can be found very rarely in international publications, but that media literacy competency is sometimes mentioned (e.g. Tyner 2007; Hobbs 2011). Media literacy competency generally refers to "the ability to critically analyze and reflect about media messages as well as to create and disseminate media messages and take action" (Tulodziecki 2012, 50). Tiede et al. (2015) underline the relevance of pedagogical media competencies for teachers' professional development. They conducted a comparative analysis of competency models and of teacher education programs in Germany and the United States.

Instruments for measuring teachers' competencies in the field of media education are scarce, but this comes as no surprise: "There are so many dimensions of media and digital literacy that it will take many years to develop truly comprehensive measures that support the needs of students, educators, policymakers and other stakeholders." (Hobbs 2010, 42). Therefore, Tulodziecki (2012) also states that "in future research the focus needs to be on the further development and validation of appropriate research instruments to assess media competence levels and their use in empirical evaluations" (52). Nevertheless, several frameworks and inventories of competencies have been developed. For teachers, three German media literacy models are of particular interest: Blömeke (2001), Bremer (2011) and Ministerium für Schule und Weiterbildung des Landes Nordrhein-Westfalen (2001). Tiede et al. (2015) give more details on these models and indicate how other colleagues developed further specifications. They also refer to the recent project $\mathrm{M}^{3} \mathrm{~K}$, Modelling and Measuring Media Competency, "which attempts to both model and measure pedagogical media competencies of preservice teachers" (Tiede et al. 2015, 535), and they conclude that "the field of modeling and measuring pedagogical media competencies deserves further research and development" (Tiede et al. 2015, 543).

\section{Objective}

The present study is part of a global research project, Media Didactica, which aims at developing a reference framework that maps out the competencies needed for teacher educators, teachers and pupils. The development of this framework and its relation with theoretical models is described in more detail in Driesen et al. (2014) and Meeus et al. (2014b).

In the present study we build on this framework with the aim of developing an easy-to-use questionnaire for self-perceived competencies in media literacy education. For teachers (and student teachers) the necessity/ desirability of measuring these competencies is twofold. First, they should be disposed to having an adequate level of media literacy themselves, and should master the competencies they are expected to foster among their students (Felini 2014). 
Teachers should also stay abreast of new media applications and sources and identify the adequate media literacy needed with them. Secondly, teachers should be disposed to having the educational competencies necessary to promote media literacy among their students. In this case, pedagogical and didactic competencies related to media literacy education are involved. The questionnaire includes both possible perspectives, i.e. the teachers' personal competencies in media literacy and their pedagogical-didactic competencies to develop media literacy in an educational context. In addition, the questionnaire is designed for all teachers, whether they want to foster media literacy within a specific subject or use an interdisciplinary approach.

The measurement of media literacy among teachers can be useful in three contexts. First, it is important for the individual teachers to be able to measure their own media literacy competencies and reflect on their improvement. However, it is not always necessary for all teachers within the school to have acquired high levels of media literacy, nor to have the same kind of media competencies; it is more important and useful to identify the media competencies of the team of teachers as a whole and to determine whether all necessary media literacy competencies are represented. Professional development can help teachers to complement each other and ultimately achieve the educational goals for their students. Finally, the measurement of teachers' media literacy competencies is useful for policy development. In this context, media literacy is considered in a broader perspective (i.e. school, regional level). An adequate view on teachers' media literacy competencies is necessary in order to assess the need to initiate specific actions to improve them.

\section{Method}

The questionnaire was developed in five stages. During the first three stages, all relevant competencies were inventoried and integrated in a preliminary questionnaire. Official documents, listings and literature were screened and compared. The inventory was refined through peer debriefing, transformed into a questionnaire and finally submitted to a group of experts. During the fourth phase, the questionnaire was critically assessed in a pilot by a limited number of teachers and student teachers. In the fifth and final stage, the questionnaire was completed by a representative sample of teachers and student teachers. Below we describe the five development stages in detail.

\section{Stage 1: Inventory of Competencies from the Literature}

The first phase of the development of the questionnaire consisted of inventorying conceptions and models of media literacy and related concepts in Dutch, English and German literature. Eight sources were identified as highly relevant: AlaMutka (2011), Buckingham (2005), EAVI (2010), Ferrari (2012), Hobbs (2010), Länderkonferenz Medienbildung (2008), Tulodziecki (2007) and Zwanenberg and Pardoen (2010). Additionally the following sources were identified as highly relevant, with a specific orientation towards education: Blömeke (2001), Bremer (2011), Ministerium für Schule und Weiterbildung des Landes NordrheinWestfalen (2001), Flemish competencies for teachers (Ministerie van de Vlaamse 
Gemeenschap, 2008), a report of the international UNESCO expert group on media literacy (UNESCO, 2008), and competencies for language teachers from the Nederlandse Taalunie (Paus, Rymenans, Gorp 2006) were studied as well.

\section{Stage 2: Conceptualization of the Questionnaire through Peer Debriefing}

The lists of media literacy competencies identified in the first step were critically appraised by four researchers, using peer debriefing (Lincoln and Guba 1985; Figg et al. 2010). Each competency was evaluated against the criteria of clearness, tangibility and specificity. Drawing on this qualitative analysis, competencies were removed and reformulated according to substantive agreement. Given the continuous and rapid developments in the field, competencies were formulated to be as timeless and generic as possible. Next, the competencies were clustered based on their thematic similarities, which resulted in three clusters: using media; understanding media; and contributing media (Driesen et al. 2014; Meeus et al. 2014b). These clusters of competencies can generally be found in competency models for media education (see also Tiede et al. 2015), though this tripartite structure is more straightforward and economical than other models found in the literature.

\section{Stage 3: Expert Inquiry}

In a third step, an expert inquiry took place. The prototype of the questionnaire was presented to 15 experts in the field of media, education, academic education and media education. Experts received the questionnaire by email and were asked to provide feedback within one month. They were requested to assess whether the competencies of the framework included all aspects of media literacy, and whether they were formulated in a consistent way and appeared in a logic structure. One researcher visited the experts to go through all of their remarks and make individual feedback reports. These reports were merged and discussed by the researchers, after which the framework was adjusted. Competencies were adjusted and wordings refined. An overview of the modifications was sent to the experts electronically, after which they had the opportunity to respond once again to the readjustments.

\section{Stage 4: Pilot Study}

Prior to the assessment of the questionnaire by a representative sample, a pilot took place with three teachers and two student teachers. They were asked to verify whether the questions were intelligible and unambiguously formulated for both target groups. The items were provided with a 5 point Likert scale, ranging from '1 - strongly disagree' to '5 - strongly agree'. A think aloud procedure was applied. Participants suggested some verbal modifications and advised to add examples or descriptions to all items.

\section{Stage 5: Survey with Teachers and Student Teachers}

Two groups of respondents participated in the study-teachers and student teachers. We chose to involve a respondent group of student teachers as well because of the possible importance of the questionnaire for teacher education. It is 
important to note that, within this group, the number of digital natives is important: it is likely that they have been trained on how to teach media literacy in their teacher education program (Meehan et al., 2015), which may affect their response behavior.

First, the questionnaire was sent to 3,164 teachers in primary and secondary education. Randomly selected mail addresses were obtained with the help of the Flemish Government Administration. We mainly focused on teachers working on media literacy based on the subjects they teach, such as Mother tongue education, Social sciences, or Project general education. Project general education is a cluster of specific subjects (mother tongue, mathematics, geology, biology and history) in the Flemish curriculum, which aims at vocational secondary education and includes a minimum of six hours per week. Next, the questionnaire was sent to 697 student teachers, more specifically to students in the last year of their teacher education program. All Flemish higher education institutes and universities offering a teacher education program were contacted. All sent us the mail addresses of their student teachers and/or gave us the opportunity to use their learning environment in order to communicate the link to the web survey.

In order to adopt an efficient way of working, the questionnaire was transformed into a web survey (Best and Krueger 2008). A possible drawback of a web survey is a lower response rate, which is generally estimated at 10\% (Dijkstra and Van der Zouwen 1982). The questionnaire was administered using Evasys software. Evasys offers the possibility to create a questionnaire using the browser, to download the data set from the server and to analyze the data using several software programs. Each respondent received an email including a link to the questionnaire and a password. The teachers and the student teachers filled in the questionnaire from two different perspectives: their personal media literacy competencies and their pedagogical-didactic competencies to promote media literacy in learners.

The questionnaire was returned by 460 teachers and 220 student teachers. After correction for missing answers, 454 questionnaires from teachers and 219 questionnaires from student teachers were used in the study. The final usable response was $14.3 \%$ for the teachers, $31.4 \%$ for the student teachers. This response rate was in line with the expectations and even surpassed it. Table 1 gives an overview of the profile of the sample of the respondent group of the teachers.

As far as gender and educational level (primary versus secondary education) are concerned, the sample has similar characteristics as the global (Flemish) population of teachers (Ministerie van de Vlaamse Gemeenschap, 2014). Compared to the population, we observed a slight overrepresentation of teachers in their forties and a slight underrepresentation of teachers in their twenties, but not to a problematic extent. Table 2 gives an overview of the 
Table 1

Profile of the respondent group - teachers

\begin{tabular}{l|c|c|c}
\hline \multirow{2}{*}{ Gender } & \multicolumn{2}{|c|}{ Respondent group Teachers } & Teacher population \\
\cline { 2 - 4 } - female & $\mathrm{n}(=454)$ & $\%$ & \\
- male & 313 & $69.4 \%$ & $72.9 \%$ \\
\hline Educational level & 137 & $30.6 \%$ & $27.1 \%$ \\
- primary education & & & \\
- secondary education & 169 & $37.2 \%$ & $47.5 \%$ \\
\hline Age & 233 & $51.3 \%$ & $52,5 \%$ \\
- 20-29 & & & \\
$-30-39$ & 106 & $8.1 \%$ & $15.7 \%$ \\
$-40-49$ & 142 & $26 \%$ & $29.1 \%$ \\
$-50-59$ & 117 & $28.7 \%$ & $24.8 \%$ \\
-+60 & 10 & $2.5 \%$ & $26.2 \%$ \\
\end{tabular}

Table 2

Subjects taught by the respondent group - teachers

\begin{tabular}{l|c|c}
\hline \multirow{2}{*}{ Taught subjects } & \multicolumn{2}{|c}{ Respondent group Teachers } \\
\cline { 2 - 3 } - Mother tongue & $\mathrm{n}(=454)$ & $\%$ \\
- Project General Education & & \\
- Social sciences & 124 & $27.3 \%$ \\
- Behavioral sciences & 83 & $18.3 \%$ \\
- Cultural sciences & 32 & $7.0 \%$ \\
- Economics & 24 & $5.3 \%$ \\
- History & 18 & $3.9 \%$ \\
- Other & 9 & $2 \%$ \\
& 7 & $1.5 \%$ \\
\hline
\end{tabular}

subjects taught by the respondents. As these data are not available for the global (Flemish) teacher population, it is not possible to make any claims about the representativeness of the sample.

The greater part of respondents teaches Mother tongue (Dutch) (27.3\%), and Project General Education (18.3\%). 22.2\% of the respondents also teach a second or a third subject, most frequently Geography or English.

The respondent group of the student teachers was composed of 177 $(80.8 \%)$ female and $42(19.2 \%)$ male respondents; representing all higher education institutes (HEIs) $(\mathrm{N}=12)$ and all universities $(\mathrm{N}=4)$ offering a teacher education program. $25.1 \%$ of the student teachers were taking a teacher education program in order to become a teacher in primary education, 56.0\% a teacher education program for the lower years of secondary education (professional bachelor) and $18.3 \%$ for the higher years of secondary education (masters). The 
average age within this group was 23.4 years $(\mathrm{SD}=4.43)$. The youngest student teacher was 19, the oldest 51.

The analytical phase consisted of an analysis of the non-response and an Exploratory Factor Analysis (EFA). We started by subjecting the items to an item-analysis. Items for which more than $5 \%$ of the respondents had not filled in an answer were considered insufficiently interpretable and were eliminated from the analysis. None of the items needed to be excluded on the grounds of this criterion. Subsequently, we eliminated all the respondents with one or more missing answers (i.e. 6 teachers and 1 student teacher). EFA with Varimax rotation was conducted using SPSS Statistics 20. The Kaiser-Meyer-Olkin measure (for all analysis $>.832$ ) and the Bartlett's test of sphericity (for each analysis $\mathrm{p}=.000$ ) verified that the data were adequate to conduct factor analysis (Loewen and Gonulal 2015). When assigning items to a factor we used the limiting value of 0.30 (Guadagnoli and Velicer 1988).

\section{Results}

Based on the identification and conceptualization process, twelve basic competencies were formulated, which could be assigned to three clusters:

a. Using media $(\mathrm{n}=3)$ : competencies reflecting the technicalinstrumental use of media.

b. Understanding media $(\mathrm{n}=6)$ : competencies in the field of (critical) understanding of media, including analysis, evaluation and reflection on media content.

c. Contributing medially $(\mathrm{n}=3)$ : competencies related to the creation and the communication of media messages as well as to participation using media.

The twelve competencies were formulated from both perspectives (personal competencies and pedagogical-didactic competencies) which resulted in 24 items. In order to measure personal competencies, the items were formulated as 'I can'-statements, e.g. "Competence 1: I can use media devices in a technical sense." In order to measure competencies for media literacy education, the items were formulated as pedagogical-didactical competencies to be promoted in learners, e.g. "Competence 1: I can teach learners how to use media devices in a technical sense." Based on the feedback generated during the pilot study (Stage 4), examples were added to the items, e.g. "Competence 1: (e.g. computer, projector, tablets, smartphone, interactive whiteboard)."

Table 3 and Table 4 show the results of the EFA for the teachers and the student teachers. Table 3 gives an overview of the results of the factor analysis for the assessment of the personal competencies in the field of media literacy. Table 4

gives an overview of the results of the factor analysis for the assessment of the pedagogical-didactic competencies.

Both for the teachers and student teachers, and both for the personal competencies and the pedagogical-didactic competencies, the EFA indicate a 
Table 3

Items and EFA results for competencies in media literacy

\begin{tabular}{|c|c|c|c|c|c|c|}
\hline \multirow[t]{2}{*}{ Personal Competencies in the Field of Media Literacy } & \multicolumn{3}{|c|}{$\begin{array}{l}\text { Teachers } \\
\text { Explained variance: } 62.5 \% \\
\text { Kaiser-Meyer-Olkin value: } \\
.856 \\
\text { Bartlett's Test of Sphericity: } \\
\text { Sig .000 }\end{array}$} & \multicolumn{3}{|c|}{$\begin{array}{l}\text { Student teachers } \\
\text { Explained variance: } 60.2 \% \\
\text { Kaiser-Meyer-Olkin value: } \\
.832 \\
\text { Bartlett's Test of Sphericity: } \\
\text { Sig .000 }\end{array}$} \\
\hline & $\begin{array}{c}\text { Comp } \\
1\end{array}$ & $\begin{array}{c}\text { Comp } \\
2\end{array}$ & $\begin{array}{c}\text { Comp } \\
3\end{array}$ & $\begin{array}{c}\text { Comp } \\
1\end{array}$ & $\begin{array}{c}\text { Comp } \\
2\end{array}$ & $\begin{array}{c}\text { Comp } \\
3\end{array}$ \\
\hline $\begin{array}{l}\text { I can use media devices in a technical sense (e.g. } \\
\text { computer, projector, tablets, smartphone, interactive } \\
\text { whiteboard). }\end{array}$ & .859 & & & .806 & & \\
\hline $\begin{array}{l}\text { I can consciously choose between different media } \\
\text { devices, based on their function (e.g. computer, } \\
\text { smartphone or tablet, navigate through hyperlinks). }\end{array}$ & .831 & & & .801 & & \\
\hline $\begin{array}{l}\text { I can purposefully use different sources of information } \\
\text { and media devices (e.g. search for information using } \\
\text { social network sites, the internet). }\end{array}$ & .593 & & & .494 & & \\
\hline $\begin{array}{l}\text { I know that media represent information in a selective } \\
\text { way and know how to interpret media messages (e.g. } \\
\text { implicit versus explicit media language, the structure of } \\
\text { a text/article/film/video/...). }\end{array}$ & & .585 & & & .546 & \\
\hline $\begin{array}{l}\text { I know how media production and distribution works } \\
\text { (e.g. from source to article, the filtering of news, the } \\
\text { intersection between politics, media and democracy). }\end{array}$ & & .839 & & & .600 & \\
\hline $\begin{array}{l}\text { I know how media content is tailored to the target } \\
\text { audience (e.g. selection possibilities, personalized on } \\
\text { line offer through cookies, newspapers/television } \\
\text { channels/websites and their target audience). }\end{array}$ & & .823 & & & .765 & \\
\hline $\begin{array}{l}\text { I can evaluate media content taking into account } \\
\text { various criteria (e.g. accuracy of information, } \\
\text { comparison of information, appreciation of aesthetic } \\
\text { aspects). }\end{array}$ & & .774 & & & .705 & \\
\hline $\begin{array}{l}\text { I am aware of the effects of media (e.g. influence on } \\
\text { purchasing behavior, undesired effects such as hate or } \\
\text { addiction). }\end{array}$ & & .522 & & & .687 & \\
\hline $\begin{array}{l}\text { I am aware of my own media behavior (e.g. copyright, } \\
\text { illegal downloads, dangerous media behavior). }\end{array}$ & & .540 & & & .684 & \\
\hline $\begin{array}{l}\text { I can create media content (e.g. write an article, create a } \\
\text { photo or video document, set up a blog). }\end{array}$ & & & .821 & & & .847 \\
\hline $\begin{array}{l}\text { I can communicate and present contents using media } \\
\text { (e.g. structure and adapt a presentation, publish media } \\
\text { content through an appropriate channel such as blogs, } \\
\text { directories, YouTube). }\end{array}$ & .416 & & .556 & .425 & & .583 \\
\hline $\begin{array}{l}\text { I can participate in the public debate through media } \\
\text { (e.g. show commitment using (social) media, contact } \\
\text { organizations by email, reader reactions or social } \\
\text { media). }\end{array}$ & & & .797 & & & .786 \\
\hline Eigenvalue & 2.00 & 4.97 & 1.11 & 1.97 & 4.70 & 1.26 \\
\hline$\%$ Explained variance & 13.3 & 33.1 & 7.4 & 13.1 & 31.3 & 8.4 \\
\hline Cronbach's alpha & .771 & .835 & .633 & .775 & .789 & .647 \\
\hline
\end{tabular}


Table 4

Items and EFA results for competencies in media literacy education Pedagogical-Didactical Competencies in the Field of
Media Literacy

\begin{tabular}{l} 
Teachers \\
Explained variance: $60.5 \%$ \\
Kaiser-Meyer-Olkin value: \\
.859 \\
Bartlett's Test of Sphericity: \\
Sig .000 \\
\hline
\end{tabular}

Student teachers

Explained variance: $64.8 \%$

Kaiser-Meyer-Olkin value: .833

Bartlett's Test of Sphericity: Sig .000

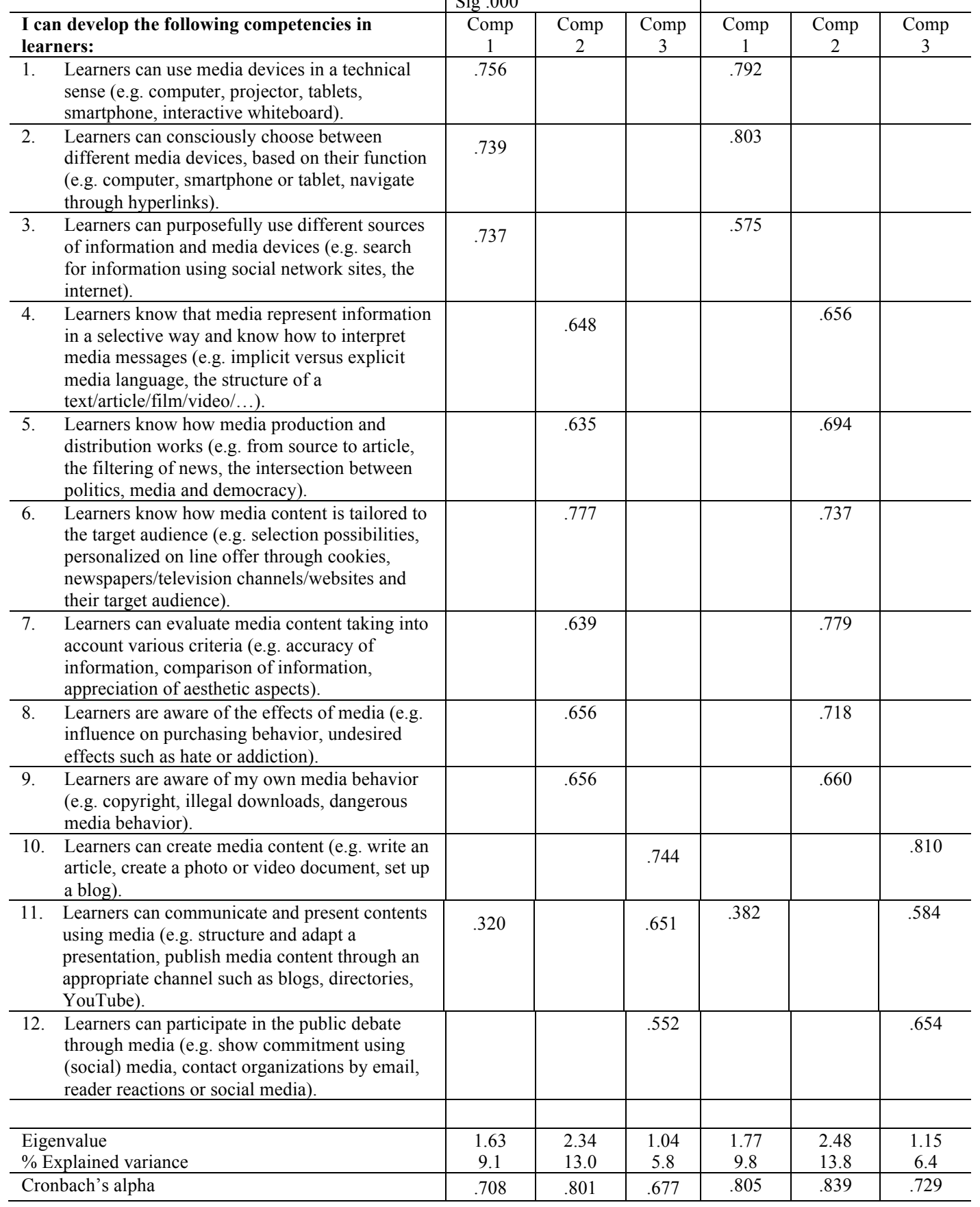


result that comprises three components with an eigenvalue $>1$ and an explained variance $>60.2 \%$. The 3 -factor structure clearly represents the initial clusters, i.e. Using media (factor 1), Understanding media (factor 2) and Contributing medially (factor 3 ). Each component had an explained variance between 5.8\% and 33.1\%.

One item (item 11) shows cross loadings on factor 1 (Using media) and factor 3 (Contributing medially). The item loadings on factor 3 are higher and also clearer for the pedagogical-didactic competencies, with a difference between the loadings of $>.200$, in favor of factor 3. The use of two verbs in these items, i.e. 'communicate' and 'present' possibly caused a cross loading on the factor Using media. In a future use of the questionnaire, we therefore suggest to use only the verb 'communicate' in this item.

As far as reliability is concerned, the following results were observed:

(i) Factor 1: Using media (3 items; $\alpha=>$.708)

(ii) Factor 2: Understanding media (6 items; $\alpha=>$.789)

(iii) Factor 3: Contributing medially (3 items; $\alpha=>.633$ )

Consequently, all factors showed a sufficient to good internal consistency (Field, 2013) and made sense in terms of content.

\section{Conclusion and Recommendations for Future Research}

If teachers are to provide their learners with effective media education they should: a) be sufficiently media literate themselves, and b) have the required competencies to promote media literacy among learners. In order to measure such competencies, a questionnaire was developed to determine the extent to which teachers grasp these competencies from both perspectives, i.e. their personal competencies in media literacy and their pedagogical-didactic competencies.

The questionnaire was developed in five stages. During stages one through three, field-related literature was studied in order to develop a relevant and exhaustive questionnaire. During stage four, this questionnaire was critically assessed by a limited pilot group. In the fifth and final stage, the questionnaire was completed by a representative sample of teachers and student teachers. The results of both response groups prove the questionnaire to be internally and externally valid and generalizable, internally consistent and reliable (EFA).

Despite these positive results some limitations and recommendations for further research can be mentioned. The questionnaire is a self-reported instrument. These kind of instruments pose a risk of misreporting by respondents (Hargittai 2005). Further, several researchers point at the possible mismatch between self-assessment measurement and performance measurement. Indeed, the actual behavior (i.e. the actions the teacher performs in reality), is to be situated in time after the assessment of his own competencies or self-efficacy (Bandura 1994). Yet, the actual behavior influences once again the future assessment the teacher will make of his own competencies (cf. Multidimensional Model of Teacher Efficacy of Tschannen-Moran et al. 1998). After all, behavior is one of the basic dimensions in Bandura's triadic reciprocal causation model (1986), next to personal factor and the social, contextual environment. In order to prevent these risks, we recommend to use the questionnaire in the two dimensions presented: as an assessment of the personal media literacy competencies, reflecting the 
teachers' self efficacy in the field of media literacy ("I can"-statements); and as an evaluation of their pedagogical-didactic competencies, giving an indication of the possible realization of their media literacy competencies in class practice ("Learners can"-statements). This way, the questionnaire shows how teachers assess their own competencies and the degree to which they think they are able to perform certain actions in an educational context. Despite these two dimensions, however, results remain at the level of teacher beliefs.

Another difficulty of self-reported instruments, observed by Hargittai (2009), is the risk of misinterpretation of terms in measurement instruments for media literacy. Digital concepts evolve quickly. In our questionnaire we neutralized this issue, by including older and newer concepts in the examples that were added to the competencies (e.g. computer versus interactive whiteboard).

All competencies are formulated in a rather generic, hence abstract way, leaving teachers to interpret the concrete form and realization of each competency themselves. As interpretations may differ, this could lead to some discussion or even misunderstandings. Therefore a further development of the questionnaire, in which the competencies are developed and formulated at a more concrete level, is required.

Only those competencies which teachers have to develop among their learners and which they are to master as well were included in the questionnaire. Pedagogical-didactic competencies were only inquired from the learners' point of view. Further research could complement the questionnaire from a methodical angle, e.g. competencies related to the use of media in the lesson preparation, execution and evaluation; to the use of media in the professionalization of the teacher and/or to the use of media for the execution of tasks within the education community (Driesen et al. 2014).

The validation study was carried out with two representative samples of teachers and student teachers. As the questionnaire includes competencies to be fostered through media education, it can be interesting to conduct a similar validation study with a sample of learners. Further, media education does not only concern teachers and their learners. In the educational process, teacher educators are included as well. They play an important part in the preparation of student teachers as adequate media educators. Consequently, the questionnaire could also be used for the latter group, if ever enriched with specific methodical competencies (the use of media in teacher education, in their professionalization and in their contacts with the education and training community).

\section{References}

Ala-Mutka, K. 2011. Mapping Digital Competence: Towards a Conceptual Understanding. Luxemburg: Institute for Prospective Technological Studies.

Arke, E.T. and B.A. Primack. 2009. "Quantifying Media Literacy: Development, Reliability, and Validity of a New Measure." Educational Media International 46 (1): 53-65. 
Bandura, A. 1986. Social Foundations of Thought and Action: A Social Cognitive Theory. Englewood Cliffs, NJ: Prentice-Hall.

Bandura, A. 1994. "Self-efficacy." In Encyclopedia of human behaviour, Vol. 4, edited by S. Ramachaudran, 71-81. New York: Academic Press. (Reprinted in H. Friedman (Ed.), Encyclopedia of mental health. San Diego: Academic Press, 1998).

Baran, S.J. 2009. Introduction to Mass Communication: Media Literacy and Culture. McGraw-Hill.

Bergsma, L.J., and M.E. Carney. 2008. "Effectiveness of Health-promoting Media Literacy Education: A Systematic Review." Health Education Research 23: 522-542.

Best, S.J., and B.S. Krueger. 2008. "Internet Survey Design." In The SAGE handbook of Online Research Methods, edited by N. Fielding, R. M. Lee, and G. Blank, 217-235. London: Sage.

Blömeke, S. 2001. "Analyse von Konzepten zum Erwerb medienpädagogischer Kompetenz. Folgerungen aus den Ansätzen von Dieter Baacke und Gerhard Tulodziecki." In Jahrbuch Medienpädagogik 2, edited by B. Bachmair, D. Spanhel, and C. D. Witt, 27-47.

Bremer, C. 2011. "Medienkompetenz in der hessischen Lehrerbildung." In Framediale - Digitale Medien in Bildungseinrichtungen, edited by $\mathrm{T}$. Knaus and O. Engel, 57-73. München: kopaed.

Buckingham, D. 2005. The Media Literacy of Children and Young People: A Review of the Research Literature. London: Ofcom.

Chang, C-S, E. Z-F. Liu, C-Y Lee, N-S Chen, D-C Hu, and C-H Lin. 2011. "Developing and Validating a Media Literacy Self-evaluation scale (MLSS) for Elementary School Students." TOJET: The Turkish Online Journal of Educational Technology 10 (2): 63-71.

Claes, E., and E. Quintelier. 2009. "Newspapers in Education: A Critical Inquiry into the Effects of using Newspapers as Teaching Agents." Educational Research 51 (3): 341-363.

Cortoni, I., V. Lo Presti, and P. Cervelli. 2015. "Digital Competence Assessment. A Proposal for Operationalizing the Critical Dimension." Journal of Media Literacy Education 7 (1): 46 -57.

Dijkstra, W., and J. Van der Zouwen. 1982. Response Behavior in the SurveyInterview. New York: Academic Press.

Driesen, A., W. Meeus, J. T'Sas, and J. Van Ouytsel. 2014. Media didactica: werkboek mediawijsheid voor lerenden, leraren en lerarenopleiders. Brugge: Die Keure.

EAVI. 2010. Study on Assessment Criteria for Media Literacy Levels, Final Report. Brussels: EAVI.

Felini, D. E. D. 2014. "Quality Media Literacy Education. A Tool for Teachers and Teacher Educators of Italian Elementary Schools." Journal of Media Literacy Education 6 (1): 28-43.

Ferrari, A. 2012. Digital Competence in Practice: An Analysis of Frameworks. Luxemburg: Institute for Prospective Technological Studies. 
Field, A. P. 2013. Discovering Statistics using SPSS (3rd edition). Los Angeles, CA: Sage.

Figg, C., M. Wenrick, C. Youker, J. Heilman, and C. Schneider. 2010. "Implications and Benefits of a Long-Term Peer Debriefing Experience on Teacher Researchers." Brock Education: a Journal of Educational Research and Practice 19 (1): 20-35.

Friesem, Y. 2013. "Review: Media Literacy in the K-12 Classroom (2012)." Journal of Media Literacy Education 5 (2). 395-396.

Friesem, Y., D. Quaglia Beltran, and E. Crane. 2014. "Media Now: A Historical Review of a Media Literacy Curriculum." Journal of Media Literacy Education 6 (2): 35-55.

Fry, K.G. 2015 "Developing Media Literacy: Managing Fear and Moving Beyond," Journal of Media Literacy Education 6 (3): 65-70.

Guadagnoli, E., and W.F. Velicer. 1988. "The Relationship of Sample Size to the Stability of Patterns." Psychological Bulletin 103 (2): 265-275.

Hargittai, E. 2005. "Survey Measures of Web-oriented Digital Literacy." Social Science Computer Review 23: 371-379.

Hargittai, E. 2009. "An Update on Survey Measures of Web-Oriented Digital Literacy." Social Science Computer Review 27 (1): 130-137.

Hobbs, R. 2010. Digital and Media Literacy: A Plan of Action (white paper). Washington D.C.: The Aspen Institute.

Hobbs, R. 2011. Digital and Media Literacy: Connecting Classroom and Culture. Thousand: Oaks: Corwin.

Hobbs, R. and R. Frost. 2003. "Measuring the Acquisition of Media-literacy Skills." Reading Research Quarterly 38 (3): 330-355.

Länderkonferenz Medienbildung. 2008. Kompetenzorientiertes Konzept für die schulische Medienbildung. s.1.

Lincoln, Y.S., and E.G. Guba. 1985. Naturalistic Inquiry. Beverly Hills, CA: Sage Publications.

Loewen, S., and T. Gonulal. 2015. "Exploratory Factor Analysis and Principal Components Analysis." In Advancing Quantitative Methods in Second Language Research, edited by L. Plonsky, 182-212. New York: Routledge.

Meehan, J., R. Brandi, S. Wells, A. Walker, and G. Schwarz. 2015. "Media Literacy in Teacher Education: A Good Fit across the Curriculum." Journal of Media Literacy Education 7 (2): 81 -86.

Meeus, W., J. Van Ouytsel, A. Driesen, and J. T'Sas. 2014a. "Media Literacy in the Digital Age. How to Benefit from Media Use while Protecting against Harm." The Journal of Didactics 5 (1\&2): 64-79.

Meeus, W., J. Van Ouytsel, A. Driesen, and J. T'Sas, 2014b. "Media Didactica: A Media Literacy Reference Framework for Learners, Teachers and Teacher Educators." Bildung mit und über Medien. Perspektiven von Bildungsforschung und Medienpädagogik. merzWissenschaft 58 (6): 4149.

Ministerie van de Vlaamse Gemeenschap. 2008. Besluit van de betreffende de basiscompetenties van de leraren. Brussel. 
Ministerie van de Vlaamse Gemeenschap. Departement Onderwijs. 2014. Statistisch Jaarboek 2013-2014. http://www.ond.vlaanderen.be/ onderwijsstatistieken/2013-2014/statistischjaarboek20132014/publicatiestatistischjaarboek2013-2014.htm. Accessed January 16, 2017.

Ministerium für Schule und Weiterbildung des Landes Nordrhein-Westfalen. 2001. Portfolio:Medien.Lehrerbildung - Info. Bönen: Verlag für Schule und Weiterbildung.

National Association for Media Literacy Education (NAMLE). Definition of Media Literacy. https://namle.net/publications/media-literacy-definitions/. Accessed August 19, 2016.

Neag, A. 2015."Media Literacy and the Hungarian National Core Curriculum - A Curate's Egg," Journal of Media Literacy Education 7 (1): 35 -45.

Pajares, F. 1992. "Teachers' Beliefs and Educational Research: Cleaning Up a Messy Construct." Review of Educational Research 62: 307-332.

Paus, H., R. Rymenans, and K.V. Gorp. 2006. Dertien doelen in een dozijn. Een Referentiekader voor taalcompetenties van leraren in Nederland en Vlaanderen. Den Haag: Nederlandse Taalunie.

Pinto, M. 2010. "Design of the IL-HUMASS Survey on Information Literacy in Higher Education: A Self-assessment Approach." Journal of Information Science 36 (1): 86-103.

Potter, W.J. 2013. "Review of Literature on Media Literacy." Sociology Compass 7 (6): 417-435.

Primack, B.A., M.A. Gold, G.E. Switzer, R. Hobbs, S.R. Land and M.J. Fine. 2006. "Development and Validation of a Smoking Media Literacy Scale." Archives of Pediatric \& Adolescent Medicine 160: 369-374.

Quin, R., and B. McMahon. 1995. "Evaluating Standards in Media Education." Canadian Journal of Educational Communication 22: 15-25.

Raeymaeckers, K. 2004. Onderzoeksrapport over de receptie van het project 'Kranten in de Klas' bij leerlingen en leerkrachten uit de derde graad van het secundair onderwijs. Gent: Universiteit Gent.

Raeymaeckers, K., P. Ugile, and T. Hoebeke. 2008. Kranten in de Klas 2008: Attitude omtrent politiek en politieke berichtgeving - kwalitatief en kwantitatief. Gent: Universiteit Gent.

Segers, K., and J. Bauwens. 2010. Maak mij wat wijs. Media kennen, begrijpen en zelf creëren. Tielt: Lannoo.

Segers, K., and N. Resmann. 2010. Kuieren in de Krant. KiK als opstap naar mediageletterdheid. Kranten in de Klas. Brussel: Vrije Universiteit Brussel.

Silverblatt, A., A. Smith, D. Miller, J. Smith, and N. Brown. 2014. Media Literacy: Keys to Interpreting Media Messages. $4^{\text {th }}$ Edition. ABC-CLIO.

Simons, M., K. Daemen, F. Hiel, J. T'Sas, and J. Van Pée. 2015. Mediawijsheid en tekstbegrip aanbrengen: kan (K)ik da took digitaal? Evaluatieonderzoek van het project Kranten in de Klas (KiK). Antwerpen: Universiteit Antwerpen. 
Singer, D., and Singer, J. 1998. "Developing Critical Viewing Skills and Media Literacy in Children." Annals of the American Academy of Political and Social Science 557: 164-179.

Tiede, J., S. Grafe, and R. Hobbs. 2015. "Pedagogical Media Competencies of Preservice Teachers in Germany and the United States: A Comparative Analysis of Theory and Practice." Peabody Journal of Education 90 (4): 533-545.

Tschannen-Moran, M., A. Woolfolk Hoy, and W.K. Hoy. 1998. "Teacher Efficacy: Its Meaning and Measure." Review of Educational Research 68: 202-248.

Tulodziecki, G. 2007. "Was Schülerinnen und Schüler im Medienbereich wissen und können sollen - Kompetenzmodell und Bildungsstandards für die Medienbildung." Medienimpulse 15 (59): 24-35.

Tulodziecki, G., and S. Grafe, 2012. "Approaches to Media literacy education in the Federal Republic of Germany. Trends and current situation." Journal of Media Literacy Education 4 (1): 44-60.

Tyner, K. 2007. "Media Literacy, Aims and Purposes of." In Encyclopedia of Children, Adolescents, and the Media, edited by J. Arnett, 523-525. London: Sage.

UNESCO. 2008. Teacher Training Curricula for Media and Information Literacy. Report of the International Expert Group Meeting UNESCO House. Paris.

Vandenbrande, K. 2005. De krant op de schoolbank en in een luie zetel. Een kwalitatief onderzoek naar de betekenis en beleving van de krant bij Vlaamse jongeren. Brussel: Vrije Universiteit Brussel - Cemeso.

Wade, T.D., S. Davidson, and J.A. O'Dea. 2002. "A Preliminary Controlled Evaluation of a School-based Media Literacy Program and Self-esteem Program for Reducing Eating Disorder Risk Factors." International Journal of Eating Disorders 33: 371-383.

Zwanenberg, F., and J. Pardoen. 2010. Handboek Mediawijsheid op school. Hoe worden kinderen mediawijs? Praktische gids en inspiratie voor het onderwijs. Leidschendam: Stichting Mijn Kind Online. 